\title{
Investments of Polish Family Businesses
}

\author{
Maciej Stradomski \\ Poznań University of Economics and Business \\ Niepodległości Avenue 10 \\ 61-875 Poznań, Poland \\ e-mail:maciej.stradomski@ue.poznan.pl
}

\section{Katarzyna Schmidt}

Poznań University of Economics and Business

Niepodległości Avenue 10

61-875 Poznań, Poland

e-mail: katarzyna.schmidt@ue.poznan.pl

\begin{abstract}
:
In this paper the authors address the issue of investments made by family businesses. Their study attempted to verify the level of investments made by Polish family businesses in comparison with the level of investments made by Polish non-family businesses. The study focused on the analysis of investment flows of Polish listed companies included in the WIG index for the years 20062018. A total of 233 companies were analyzed, including 177 non-family businesses and 56 family businesses. The results corroborated the argument that Polish listed non-family businesses invest much more money than family businesses. It was also observed that only a small percentage of companies in both groups invest their finances in research and development.

Keywords: family businesses, investments, research and development, nonfamily businesses.
\end{abstract}

\section{Introduction}

Over the years, family businesses have become a subject of interest for a growing number of researchers, scientists, economists and state decision-makers. This increased interest is motivated not only by the prevalence of family businesses in economies [4], but also from their unique character. "In the literature, family businesses have been presented as combinations of two systems that overlap and interact: the emotion-oriented family system that focuses on non-economic goals and the results-oriented business system that focuses on the economic goal" [23, p. 351]. The combination of these two different systems makes strategic decision making in family businesses extremely complex, and the decision-making process itself often differs significantly from that of 
non-family businesses. Investment is one of the areas that may be affected by the specific ownership structure of family businesses. Making investments by business operators is crucial for the company to achieve a competitive advantage, develop or, in the long run, survive. And although the area of investment is so important for enterprises, so far little attention has been paid to this issue from the perspective of family businesses [17]. This is all the more surprising given that "investment might be a channel that helps explain the differential performance of the two types of businesses by focusing on strategic, long-term horizons" [6, p. 1035].

In view of the above, the authors decided to focus their study on the area of investments made by family businesses. They aimed at the verification of the level of investments made by Polish family businesses in comparison with the level of investments made by Polish non-family businesses.

The paper has been divided into three parts. The first part presents a review of the literature concerning the issue in question, including elements that may determine the difference between family businesses in terms of investment. The second part presents the data and methodology used in the study, and its results. The last part is a summary that concludes the work presented in the paper and points to issues that may contribute to further, in-depth analyses.

\section{Literature Review}

The discussion of family businesses often reveals that they are inherently conservative and with significant risk aversion [16], [5], [22]. Investment, and in particular R\&D expenditure, is associated with uncertainty, which may discourage businesses from becoming active [11]. In every situation in which we are dealing with risk, there is a certain probability of success and failure. Failure can result from making a wrong decision or achieving a goal below expectations. The adoption of the status quo by companies, whether family or non-family, seems impossible nowadays [26]. So the problem to be addressed is whether family businesses invest, but they invest less than non-family businesses, or, perhaps, the ownership structure does not have any impact on the activity in this area.

In the vast majority of the literature, which somehow raises the issue of family businesses and their financial decisions, two basic factors that may influence the uniqueness of family businesses in terms of investment are given:

- family risk preferences,

- family horizons.

\subsection{Family Risk Preferences}

Family businesses certainly perceive the risk of a given situation differently than non-family businesses. This may result from the fact that families are often directly linked to the assets of the company. Secondly, families are also emotionally linked to their companies. The relation between assets and the company results from the fact that the owner and other family members hold significant shares in the company. As a result, the company's assets are a family assets and its survival directly affects the family's well-being [5], [2]. The emotional connection, in turn, results from the very personal treatment of the family business, especially by the founders, who see their work as another "child" [25], which must be maintained and developed without taking unnecessary risks that could in any way endanger prosperity. "Business owners and their family members working in family businesses very often work as volunteers themselves - not counting the time spent in business" [25, p. 47]. The issue of trust and favouritism, often referred to as nepotism, also arises in place of an emotional relationship. It often happens that the owner prefers to employ a less educated family member than a person from outside. This procedure is even more visible in succession processes, when it becomes more important to keep the company in the hands of the family than finding a competent successor [6]. Keeping the company in the hands of the family is at the same time one of those factors that may induce the family business to undertake activities 
characterized by above-average risk. Risky activities, characterized by a high probability of failure, will be more often undertaken by family companies than non-family ones if these activities make up a chance to keep the company in the hands of the family. The above discussion allows us to state that "family businesses are risk willing and risk averse at the same time because a prime motivation of owners is to preserve their socioemotional wealth" [14, p. 134]. It seems, therefore, that different motives governing family businesses may balance aversion and willingness to risk.

The general investment tendency of family businesses is confirmed by the research conducted by Ronald C. Anderson and David M. Reeb [1], who analyzed S\&P 500 companies in the period 1992-1999 and showed that family businesses have a higher Tobin's q-ratio ${ }^{1}$ and achieve better results than non-family businesses. At the same time, by examining the tendency of companies to incur expenses on research and development Ettore Croci, and colleagues [11] showed that family businesses engage less capital in R\&D and risky investments than non-family businesses (survey on European companies in 1998-2008). The same conclusions were reached by Fernando Muñoz-Bullón and Maria J. Sanchez-Bueno [24] who surveyed Canadian listed companies in the period 2004-2009 and Joern H. Block [7] who verified the behavior of family listed companies included in the S\&P 500 index. An interesting perspective of the problem perception was presented by James Chrisman and Pankaj Patel [9] who proved that family businesses invest less in research and development, but are able to increase their expenditures on this objective to a greater extent if the results achieved are lower than the aspirations of the owners.

\subsection{Family Horizons}

In their research on family businesses Renato Tagiuri and John A. Davis [29] showed that $80 \%$ of the population they surveyed considered long-term survival to be an important goal, and $44 \%$ a major goal, and although a long time had passed since the survey, this preference seems to have been widely recognized and accepted in the literature. Longevity, the transfer of the company to the next generation, is the perspective that family businesses face. For many companies, ensuring the longevity of a company is more important than maximizing profit or continuously increasing profitability [17]. Investing "with a long-term perspective, possesses strong incentives to engage in investment activities that ensure the long-term viability and health of the firm" [3, p. 1746]. This means that family businesses will be very cautious about investing and will assess emerging investment opportunities not only from the perspective of profitability, but also, and above all, from the perspective of business continuity. ${ }^{2}$ This eliminates the myopia of which external managers seeking to maximize short-term profits in order to obtain higher remuneration are often accused [3]. According to Thomas Zellweger [32], a long-term approach means that there are two strategies that family businesses can follow in their investment activities. As the marginal investment risk decreases over time, "long-term-oriented businesses can invest in projects with equal risk, but lower returns compared to the short-term investor" [32, p. 9] or "long-term-oriented businesses can invest in projects with equal returns but higher risk compared to the short-term investor" [32, p. 9]. It all depends on how much risk the owner is willing to accept. Another issue that researchers point out in the case of family businesses is the ability to pass on knowledge from generation to generation [6]. Several-century-long accumulation of secret recipes, know-how or specialist knowledge allows family businesses to take action aimed at research and development. In the literature one can even come across the notion of innovative potential of family businesses in the aspect of knowledge diffusion [18].

An interesting study on longevity issues was conducted by Suzanne Landry, and colleagues [20], who proved that family businesses in which a family member is the owner and direct manager of the company prefer to acquire assets in order to accumulate wealth and pass it on to future generations, while family businesses, where the founder is the only member of the family involved in business, opt for the lease of assets. The willingness and perspective to transfer the company to the next generation motivates the owner to accumulate wealth for ownership. The above may suggest, however, that family businesses will invest, but to a large extent in fixed assets rather than 
research and development. This view is distorted by the study conducted by Shou-Min Tsao and Wei-Hao Lien [30], who, when analyzing publicly listed Taiwanese companies for the period 20002009 , proved that there is a statistically significant, positive correlation between family businesses' R\&D spending and internalization. Such a correlation does not exist in the case of non-family businesses. Expansion into foreign markets fits in perfectly with long-term strategies, and increased spending on $\mathrm{R} \& \mathrm{D}$ suggests that in the long run, companies are able to take risky actions if they contribute to the development and maintenance of a family business.

The literature review presented in this section clearly shows that the issue of investment by family businesses is extremely complex and complicated, and the results of the research are heterogeneous. Due to the unique nature of family businesses, many situations or factors can be seen in different ways, which means that the actual decisions of family businesses may differ from theoretical assumptions. Taking into account the above and the fact that, to the best of the authors' knowledge, there are no sources that comprehensively and exhaustively treat the investments of Polish family businesses, a decision was made to analyze the phenomenon.

\section{Data, Methodology and Results}

In order to achieve the main goal of the paper, the authors conducted a survey on Polish listed companies based on data obtained from the Notoria database for the years 2006-2018. The survey used the information contained in cash flows. The cash flow approach, in comparison to the more frequently used balance sheet approach, is a great advantage of the survey, because it allows for accurate tracking of the movement of the company's cash resources during the period in which they took place. In addition, the cash flow statement details the category of investment, allowing real changes to be observed over the years. ${ }^{3}$

The companies included in the WIG index according to the yearbook published by the WSE in 2019 [15] were selected for the survey. In total, 346 companies are listed in the yearbook. After excluding foreign companies, companies with a fiscal year not equal to calendar year, companies with incomplete data and companies from the financial sector (active in investment, brokerage, insurance, and liabilities), as many as 233 companies remained to be analyzed.

The group of companies identified as described above was divided into two categories: nonfamily listed businesses and family listed businesses. Definition of what make a business a family business was the fundamental issue at the stage of dividing a given population into the indicated categories. Determination of the family structure of a given company has posed problems for researchers ever since they started dealing with family businesses, which have a specific ownership structure [27], [10]. However, in accordance with the approach already developed by the authors, ${ }^{4}$ for the purposes of this study, family businesses were considered to be those in which:

- at least one member of the family or a family together holds at least $33 \%$ of the votes in the company,

- at least one member of the family is a member of the company's board of directors or supervisory board,

- the company has all the features of a family business.

Eventually, 177 companies were identified as non-family businesses, and 56 companies were identified as family businesses. The companies selected belonged to different sectors and achieved different levels of sales revenues. Therefore, in order to verify the comparability of the two groups, their average size was calculated by logarithmizing the sales revenues generated by the companies in 2018. Based on the results obtained, it was concluded that the groups under examination are comparable, as their average size differs insignificantly ${ }^{5}$. The results are presented in the table below:

Table 1. Size of companies in the groups under analysis.

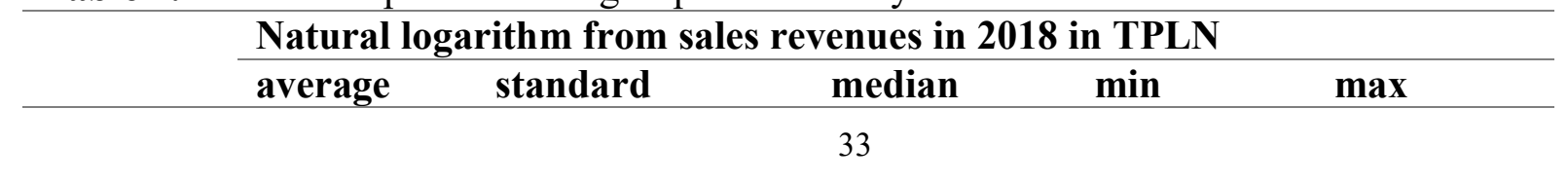




\section{deviation}

\begin{tabular}{lccccc}
$\begin{array}{l}\text { Non- } \\
\text { family } \\
\text { businesses }\end{array}$ & 11.92 & 2.43 & 12.03 & 1.10 & 18.28 \\
\hline $\begin{array}{l}\text { Family } \\
\text { businesses }\end{array}$ & 12.04 & 2.03 & 12.31 & 4.50 & 15.83 \\
\hline
\end{tabular}

Source: prepared by the authors based on the data in the Notoria database.

The next step in the analysis was to verify the level of investment cash flows of companies over the years. Using annual cash flow statements, lists were prepared in which the average level of investments was calculated for each year. The number of companies analyzed in particular years is not constant, which is due to the fact that some companies entered the main market of the WSE later.

The data revealed that in the years 2006-2018, the flows are negative in each year, i.e. the companies invested more than they sold their accumulated assets. However, the difference in the level of investment is very clear. Non-family businesses invested much more than family businesses - on average, investment flows of non-family businesses were six times higher. This dependence does not occur in 2011 only, when family businesses had on average a higher level of investments (non-family businesses: -14,817.88 thousand zlotys and family businesses: -69,309.00 thousand zlotys). However, this deviation results from several anomalies, such as: in the group of familyowned companies - a one-off significant increase in expenses of Cyfrowy Polsat S.A. ${ }^{6}$ and in the group of non-family businesses - significant divestments of several large companies. ${ }^{7}$ All in all, the above situation resulted in a disturbance of the sample. Therefore, the authors made a partial adjustment, excluding Cyfrowy Polsat S.A. from the set of family data of listed companies. The adjustment of the sample smoothed out the cash flows (change in the volatility ratio from $65.63 \%$ to $35.54 \%$ compared to $32.24 \%$ for non-family businesses) from -11,274.58 thousand zlotys to $34,207.56$ thousand zlotys. It is worth noting, however, that in 2011, even after the adjustment, the investment flows of family businesses were higher. 
Table 2. Average investment cash flows of non-family and family businesses - comparison.

\begin{tabular}{|c|c|c|c|c|c|c|c|}
\hline Data in TPLN & 2006 & 2007 & 2008 & 2009 & 2010 & 2011 & 2012 \\
\hline $\begin{array}{l}\text { Investment flows } \\
\text { non-family } \\
\text { businesses }\end{array}$ & $\overline{113,383.67}$ & $-90,923.71$ & $\overline{1} 12,960.28$ & $\overline{101,174.75}$ & $117,457.96$ & $\begin{array}{l}- \\
14,817.88\end{array}$ & $\begin{array}{l}- \\
150,970.83\end{array}$ \\
\hline $\begin{array}{l}\text { Investment flows } \\
\text { family businesses }\end{array}$ & $-13,342.90$ & $-34,510.74$ & $-33,763.05$ & $-13,445.33$ & $-15,358.56$ & $\begin{array}{l}- \\
69,309.00\end{array}$ & $-7,168.08$ \\
\hline $\begin{array}{l}\text { Investment flows } \\
\text { family businesses } \\
\text { without Cyfrowy } \\
\text { Polsat }\end{array}$ & $-12,965.59$ & $-34,207.56$ & $-33,283.61$ & $-12,323.44$ & $-14,076.87$ & $\overline{18,180.92}$ & $-11,274.58$ \\
\hline Data in TPLN & 2013 & 2014 & 2015 & 2016 & 2017 & 2018 & \\
\hline $\begin{array}{l}\text { Investment flows } \\
\text { non-family } \\
\text { businesses }\end{array}$ & $-59,464.04$ & $\begin{array}{l}- \\
107,312.75\end{array}$ & $\begin{array}{l}- \\
105,544.07\end{array}$ & $-94,788.10$ & $-82,107.51$ & $\overline{-} 97,714.27$ & \\
\hline $\begin{array}{l}\text { Investment flows } \\
\text { family businesses }\end{array}$ & $-14,858.58$ & $-34,005.81$ & $-13,989.54$ & $-11,807.26$ & $-27,513.69$ & $\overline{-} 26,022.23$ & \\
\hline $\begin{array}{l}\text { Investment flows } \\
\text { family businesses } \\
\text { without Cyfrowy } \\
\text { Polsat }\end{array}$ & $-16,951.88$ & $-19,905.92$ & $-18,631.94$ & $-18,411.03$ & $-22,733.94$ & $\begin{array}{l}- \\
24,904.45\end{array}$ & \\
\hline
\end{tabular}

Source: prepared by the authors based on the data in the Notoria database.

A thorough analysis of the potential causes of such large differences in the level of investment flows between the two groups revealed an interesting phenomenon - family businesses are often not present in the sectors ${ }^{8}$ where non-family businesses are present. Sectors which in most cases do not include Polish listed family businesses are very capital-intensive, e.g. industrial construction, distribution of fuels and gas, power engineering, renewable energy, metal mining, coal mining or extraction and production. It seems that capital necessary for the operation of this type of enterprises is the barrier to the presence of family businesses in these sectors; due to their short history family businesses have not yet managed to accumulate sufficient capital (Polish family businesses are usually only before or in the phase of the first succession [21]).

Taking into account the above, it was decided to carry out an additional analysis, which included enterprises from the same sectors in both groups. The application of the additional restrictive condition resulted in the inclusion of 133 companies from 26 different sectors ${ }^{9}$ in the population surveyed, including 84 non-family listed companies and 49 family listed companies.

Due to the change in the number of particular groups, it was decided to verify their comparability again by analyzing the average size of companies. The results obtained allow us to conclude that the samples were perfectly matched in terms of size, as the difference between the average for non-family businesses and family businesses is only 0.07 . The results are presented in the table below.

Table 3. Size of enterprises in the groups under analysis after adjustment of sectors.

\begin{tabular}{|c|c|c|c|c|c|}
\hline & \multicolumn{5}{|c|}{ Natural logarithm from sales revenues in 2018 in TPLN } \\
\hline & average & $\begin{array}{l}\text { standard } \\
\text { deviation }\end{array}$ & median & $\min$ & $\max$ \\
\hline $\begin{array}{l}\text { Non- } \\
\text { family } \\
\text { businesses }\end{array}$ & 11.99 & 1.89 & 12.09 & 7.13 & 16.51 \\
\hline $\begin{array}{l}\text { Family } \\
\text { businesses }\end{array}$ & 11.92 & 2.06 & 12.12 & 4.50 & 15.67 \\
\hline
\end{tabular}

Source: prepared by the authors based on the data in the Notoria database. 
Similarly, as in the first case, the next step was to create a list of the average level of investment flows for groups of companies in the years 2006-2018. Due to the fact that Cyfrowy Polsat S.A. remained in the group of family businesses, the study was conducted both before and after its exclusion.

As in the case of the first analysis, larger investments were made by non-family businesses, with a deviation in 2011, however, the existing differences are smaller. Due to the exclusion of Cyfrowy Polsat S.A., throughout the entire time series, non-family listed companies have invested more than family businesses. On average, investment flows of non-family businesses were three times higher and their level ranged from $-38,228.05$ thousand zloty to $-59,355.56$ thousand zloty. The coefficient of variation for non-family businesses was $24 \%$, and for family businesses $73 \%$ (after the exclusion of Cyfrowy Polsat S.A. it was 37\%).

Table 4. Average investment cash flows of non-family and family businesses - after sector adjustment.

\begin{tabular}{|c|c|c|c|c|c|c|c|}
\hline Data in TPLN & 2006 & 2007 & 2008 & 2009 & 2010 & 2011 & 2012 \\
\hline $\begin{array}{l}\text { Investment flows } \\
\text { non-family } \\
\text { businesses }\end{array}$ & $\begin{array}{l}- \\
59,355.56\end{array}$ & $-\overline{66,706.93}$ & $-58,149.74$ & $\overline{56,864.67}$ & - & $-\overline{45,815.10}$ & $-56,272.05$ \\
\hline $\begin{array}{l}\text { Investment flows } \\
\text { family businesses }\end{array}$ & $\begin{array}{l}- \\
14,929.15\end{array}$ & $-\overline{34,779.00}$ & $-36,730.79$ & $-\overline{12,465.64}$ & $-\overline{16,666.88}$ & - & $-6,853.78$ \\
\hline $\begin{array}{l}\text { Investment flows } \\
\text { family businesses } \\
\text { without Cyfrowy } \\
\text { Polsat }\end{array}$ & - & $-\overline{34,432.79}$ & $-36,268.64$ & $-\overline{11,123.43}$ & - & $\overline{20,400.01}$ & $-11,513.12$ \\
\hline Data in TPLN & 2013 & 2014 & 2015 & 2016 & 2017 & 2018 & \\
\hline $\begin{array}{l}\text { Investment flows } \\
\text { non-family } \\
\text { businesses }\end{array}$ & $-\overline{38,228.05}$ & $\overline{-} 38,284.06$ & $-54,156.04$ & $\overline{84,446.97}$ & $-\overline{42,761.61}$ & $\begin{array}{l}- \\
39,655.05\end{array}$ & \\
\hline $\begin{array}{l}\text { Investment flows } \\
\text { family businesses }\end{array}$ & - & - & $-13,148.67$ & $-8,056.79$ & 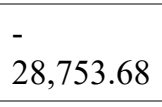 & 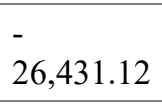 & \\
\hline $\begin{array}{l}\text { Investment flows } \\
\text { family businesses } \\
\text { without Cyfrowy } \\
\text { Polsat }\end{array}$ & - & - & $-18,464.59$ & - & $-\overline{23,302.71}$ & $-\overline{25,158.85}$ & \\
\hline
\end{tabular}

Source: prepared by the authors based on the data in the Notoria database.

As indicated in the literature review, in addition to a general verification of the level of investment flows, it is also worth analyzing R\&D spending, as it is perceived as more risky [19] and necessary for a company to supply new products or services to the market and remain competitive [7].

Therefore, in the groups under analysis adjusted by sector, lists presenting average R\&D expenditures in the years 2006-2018 were prepared. For non-family listed companies, the average level of R\&D expenditures ranged from $-6,600,000$ zloty to $-38,142,000$ zloty, with the first flows in the surveyed group appearing only in 2010. In the case of family businesses, average R\&D expenditures ranged from $-5,271,000$ zloty to $-29,134,000$ zloty, and the first R\&D flows appeared as early as 2007. It follows from the above that the difference between the groups under study is much smaller in the case of $R \& D$ expenditures than in the case of total investment flows.

It should be noted at the same time that the amounts specified above in the case of nonfamily businesses were invested over the years only by 4 companies, one each from the mechanical equipment, games, medicines, and IT systems sectors, and in the case of family businesses by 2 companies, i.e. one from the electrical equipment and one from the games sector. The above results 
allow us to conclude that few Polish listed companies allocate funds to research and development, regardless of its ownership structure.

Table 5. Average expenditure on research and development of non-family and family businesses comparison after adjustment of sectors.

\begin{tabular}{|c|c|c|c|c|c|c|c|}
\hline Data in TPLN & 2006 & 2007 & 2008 & 2009 & 2010 & 2011 & 2012 \\
\hline $\begin{array}{l}\text { R\&D expenditure } \\
\text { by non-family } \\
\text { businesses }\end{array}$ & & & & & $-6,600.00$ & $-1,772.00$ & $-8,200.00$ \\
\hline $\begin{array}{l}\text { R\&D expenditure } \\
\text { by family } \\
\text { businesses }\end{array}$ & & $-5,271.00$ & $-9,228.00$ & $-8,168.00$ & $-9,641.00$ & $\overline{16,957.00}$ & $-27,423.00$ \\
\hline $\begin{array}{l}\text { R\&D expenditure } \\
\text { by family } \\
\text { businesses } \\
\text { without Cyfrowy } \\
\text { Polsat }\end{array}$ & & $-5,271.00$ & $-9,228.00$ & $-8,168.00$ & $-9,641.00$ & $\overline{16,957.00}$ & $-27,423.00$ \\
\hline Data in TPLN & 2013 & 2014 & 2015 & 2016 & 2017 & 2018 & \\
\hline $\begin{array}{l}\text { R\&D expenditure } \\
\text { by non-family } \\
\text { businesses }\end{array}$ & $-4,000.00$ & $-4,144.50$ & $-20,512.33$ & $\begin{array}{l}- \\
24,727.00\end{array}$ & $-\overline{29,322.33}$ & $\begin{array}{l}- \\
38,142.00\end{array}$ & \\
\hline $\begin{array}{l}\text { R\&D expenditure } \\
\text { by family } \\
\text { businesses }\end{array}$ & $\begin{array}{l}- \\
29,134.00\end{array}$ & $\begin{array}{l}- \\
27,076.00\end{array}$ & $-11,276.62$ & $\begin{array}{l}- \\
16,075.00\end{array}$ & $\begin{array}{l}- \\
13,541.00\end{array}$ & - & \\
\hline $\begin{array}{l}\text { R\&D expenditure } \\
\text { by family } \\
\text { businesses } \\
\text { without Cyfrowy } \\
\text { Polsat }\end{array}$ & $\begin{array}{l}- \\
29,134.00\end{array}$ & $\begin{array}{l}- \\
27,076.00\end{array}$ & $-11,276.62$ & $-\overline{16,075.00}$ & $-\overline{13,541.00}$ & $\begin{array}{l}- \\
14,302.50\end{array}$ & \\
\hline
\end{tabular}

Source: prepared by the authors based on the data in the Notoria database.

\section{Conclusion}

The aim of this study was to verify the level of investments made by Polish family businesses in comparison with the level of investments made by Polish non-family businesses. The analysis was conducted on data obtained for Polish listed companies for the years 2006-2018.

The results revealed that Polish listed companies invest more than they sell their accumulated assets, because over the years the average investment cash flows were negative. At the same time, non-family businesses had a higher level of investment flows than Polish family businesses. This relation proved true for the analysis made before and after the adjustment of sectors. Additionally, the verification of the level of expenditures of family and non-family businesses on research and development does not help to clearly determine the group, which invests more in this area. Both in the group of non-family businesses and in the group of family businesses, the number of companies investing in R\&D did not exceed $5 \%$ of the total number of companies in a given category.

In the light of the study carried out, can the myth of family businesses as conservative companies and those characterized by aversion to risk be disproved? Certainly not. Nevertheless, the analysis presented above showed that family businesses "often face paradoxes such as balancing traditions from the past while keeping up with innovation and change, or the question of family liquidity versus business growth" [13, p. 4].

At the same time, as indicated by Joanna Sadowska [26], the fact that the level of investments of all Polish companies is low, especially in this most innovative area, i.e. research and development, is worrying. Regardless of the ownership structure owned by the company, the level 
of expenditure on research and development, as well as the number of companies that decide to allocate capital to this area is very small. Perhaps, therefore, the thesis put forward by George Tanewski, and colleagues [31] that the greatest impact on investment activity of both non-family and family businesses has a strategic orientation, i.e. the type of implemented strategy, is true. In the case of Polish family businesses, it can also be assumed that the low level of investment results from the upcoming wave of succession, which is just beginning in the Polish economy. It seems reasonable that the doyen will limit investments before the succession, because the uncertainty connected with this process makes increased investment uneconomical.

This issue, however, goes beyond the area of this article, while encouraging the authors to conduct further, in-depth study on the subject of family business investments. It seems that the identification of specific micro- and macro-economic factors influencing the investments of companies in different economies could be the basis for an attempt to answer the question whether the ownership structure is the real determinant differentiating the investment expenditures of family and non-family businesses.

\section{References}

1. Anderson, R. C., and D. M Reeb. Founding-family ownership and firm performance: evidence from the S\&P 500, The Journal of Finance 58 (3), 2003, pp. 1301-1328.

2. Anderson, R. C., and D. M. Reeb. Board composition: Balancing family influence in S\&P 500 firms. Administrative Science Quarterly, 49 (2), 2004, pp. 209-237.

3. Anderson, R. C., A. Duru, and D. M Reeb. Investment policy in family controlled firms, Journal of Banking \& Finance 36 (6), 2012, pp. 1744-1758.

4. Bennedsen, M., K. M. Nielsen, F. Pérez-González, and D. Wolfenzon. Inside the family firm: The role of families in succession decisions and performance, The Quarterly Journal of Economics 122 (2), 2007, pp. 647-691.

5. Bertrand, M., and A. Schoar. The role of family in family firms, Journal of Economic Perspectives 20 (2), 2006, pp. 73-96.

6. Bianco, M., M. E. Bontempi, R. Golinelli, and G. Parigi. Family firms' investments, uncertainty and opacity, Small Business Economics 40 (4), 2013, pp. 1035-1058.

7. Block, J. H. R\&D investments in family and founder firms: An agency perspective, Journal of Business Venturing 27 (2), 2012, pp. 248-265.

8. Blose, L. E., and J. C. Shieh. Tobin's q-Ratio and market reaction to capital investment announcements, Financial Review 32 (3), 1997, pp. 449-476.

9. Chrisman, J. J., and P. C. Patel. Variations in R\&D investments of family and nonfamily firms: Behavioral agency and myopic loss aversion perspectives, Academy of Management Journal 55 (4), 2012, pp. 976-997.

10. Collins, L., and N. O'Regan. The evolving field of family business, Journal of Family Business Management 1 (1), 2011, pp. 5-13.

11. Croci, E., J. A. Doukas, and H. Gonenc. Family control and financing decisions, European Financial Management 17 (5), 2011, pp. 860-897.

12. Cyfrowy Polsat S.A. Raport roczny spółki Cyfrowy Polsat S.A. za rok obrotowy zakończony 31 grudnia 2011 roku, 2012, accessed 25 October, 2019. https://grupapolsat.pl/pl/relacjeinwestorskie/centrum-wynikow/centrum-wynikow\#2011.

13. Finstorp A., and F. Padang. R\&D Investments in Family firms. A perspective of Swedish Family firms, Jönköping University, Master Thesis, 2016.

14. Gómez-Mejía, L. R., K. T. Haynes, M. Núñez-Nickel, K. J. Jacobson, and J. Moyano-Fuentes. Socioemotional wealth and business risks in family-controlled firms: Evidence from Spanish olive oil mills, Administrative Science Quarterly 52 (1), 2007, pp. 106-137.

15. GPW. Rocznik giełdowy. Główny rynek GPW w 2018 roku, Warszawa, 2019. Accessed 8 October, 2019. https://www.gpw.pl/biblioteka-gpw-lista?gpwlc_id=10. 
16. Hiebl, M. R. Risk aversion in family firms: what do we really know? The Journal of Risk Finance 14 (1), 2012, pp. 49-70.

17. Hirigoyen, G., and D. M. Ousseini. Investment Decisions in Unlisted Family firms, International Journal of Economics \& Management Sciences 6 (1), 2017, pp. 1-8.

18. Janczewska, D. Dyfuzja wiedzy a kształtowanie potencjału innowacyjnego przedsiębiorstw rodzinnych, Przedsiębiorczość $i$ Zarzadzanie 16 (7), part 2 Firmy rodzinne - doświadczenia $i$ perspektywy zarzadzania, 2015, pp. 239-252.

19. Kor, Y. Y. Direct and interaction effects of top management team and board compositions on R\&D investment strategy, Strategic Management Journal 27 (11), 2006, pp. 1081-1099.

20. Landry, S., A. Fortin, and A. Callimaci. Family firms and the lease decision, Journal of Family Business Strategy 4 (3), 2013, pp.176-187.

21. Lewandowska A., E. Więcek-Janka, A. Hadryś-Nowak, and M. Wojewoda. Model 5 poziomów definicyjnych firm rodzinnych. Podstawy metodyczne $i$ wyniki badań firm rodzinnych $w$ Polsce, Report on the study carried out within the framework of the project „Statystyka Firm Rodzinnych” [Statistics of family controlled firms], Publisher: Instytut Biznesu Rodzinnego, Poznań, 2016.

22. Morck, R., and B. Yeung. Agency problems in large family business groups, Entrepreneurship Theory and Practice 27 (4), 2003, pp. 367-382.

23. Motylska-Kuzma, A. The financial decisions of family firms. Journal of Family Business Management 7 (3), 2017, pp. 351-373.

24. Muñoz-Bullón, F., and M. J. Sanchez-Bueno. The impact of family involvement on the R\&D intensity of publicly traded firms, Family Business Review 24 (1), 2011, pp. 62-70.

25. PARP. Firma $w$ rodzinie czy rodzina $w$ firmie. Metodologia wsparcia firm rodzinnych, Warszawa, 2012.

26. Sadkowska, J. Aktywność badawczo-rozwojowa jako determinanta wzrostu innowacyjnego firm rodzinnych, Przedsiębiorczość i Zarzadzanie, 16(7), part. 2 Firmy rodzinne-doświadczenia $i$ perspektywy zarzadzania, 2015, pp. 155-167.

27. Sharma, P. An overview of the field of family business studies: Current status and directions for the future, Family business Review 17 (1), 2004, pp. 1-36.

28. Stradomski, M., and M. Mikutowski. Aktywność firm rodzinnych na rynku fuzji i przejęć, Przedsiębiorczość i Zarządzanie 7 (19/1), 2018, pp. 163-176.

29. Tagiuri, R., and J. A. Davis. On the goals of successful family companies, Family Business Review 5 (1), 1992, pp. 43-62.

30. Tsao, S. M., and W. H. Lien. Family management and internationalization: The impact on firm performance and innovation, Management International Review 53 (2), 2013, pp. 189-213.

31. Tanewski, G. A., D. Prajogo, and A. Sohal. Strategic Orientation and Innovation Performance Between Family and Non-Family Firms. A paper presented at the $48^{\text {th }}$ World Conference of the International Council of Small Business, Belfast, June 2003.

32. Zellweger, T. Time horizon, costs of equity capital, and generic investment strategies of firms, Family Business Review 20 (1), 2007, pp. 1-15. 
List of sectors after group adjustment

\begin{tabular}{|c|c|c|c|}
\hline No & Sector & $\begin{array}{l}\text { Non-family } \\
\text { businesses }\end{array}$ & $\begin{array}{l}\text { Family } \\
\text { businesses }\end{array}$ \\
\hline 1. & every day use goods & 2 & 1 \\
\hline 2. & general construction & 2 & 2 \\
\hline 3. & games & 7 & 1 \\
\hline 4. & hotels and restaurants & 2 & 1 \\
\hline 5. & iron and steel metallurgy & 5 & 1 \\
\hline 6. & $\begin{array}{l}\text { construction and telecommunication } \\
\text { installations }\end{array}$ & 2 & 2 \\
\hline 7. & civil engineering & 2 & 2 \\
\hline 8. & building materials & 8 & 4 \\
\hline 9. & clothes and shoes & 3 & 6 \\
\hline 10. & paper and packaging & 1 & 2 \\
\hline 11. & manufacture of medicines & 5 & 1 \\
\hline 12. & recycling & 1 & 1 \\
\hline 13. & sale of real estate & 7 & 4 \\
\hline 14. & electrical and electronic equipment & 1 & 1 \\
\hline 15. & IT hardware & 1 & 1 \\
\hline 16. & IT systems & 5 & 1 \\
\hline 17. & telecommunication & 2 & 1 \\
\hline 18. & transport & 3 & 1 \\
\hline 19. & plastics & 2 & 1 \\
\hline 20. & electrical equipment & 6 & 2 \\
\hline 21. & mechanical equipment & 5 & 4 \\
\hline 22. & services for enterprises & 3 & 1 \\
\hline 23. & publishing house & 1 & 2 \\
\hline 24. & metallurgical products & 2 & 1 \\
\hline 25. & metal products & 2 & 1 \\
\hline 26. & food & 4 & 4 \\
\hline
\end{tabular}

Source: prepared by the authors.

\section{Notes}

1. More about Tobin's q-ratio in [8].

2. It is coherent with the conclusion presented in Section 2.1. Family businesses are focused not only on the profitability but also or maybe in some cases primarily on the long-term business survival; hence they are unlikely to undertake risky investment projects. However, if there is a risk of losing control over the company (for instance through a hostile takeover), then to avoid this, the family business will be able to take action at above-average risk.

3. Another study on the Polish market, known to the authors, was conducted on the basis of balance sheet data [26].

4. For the purposes of other publications, the authors have developed a definition of a family business, which they use in their research. For details, see [28].

5. The Authors are aware that more in-depth analysis concerning the relation between investment and assets would be valuable, therefore this is the area of subsequent research.

6. In 2011, Cyfrowy Polsat S.A. acquired $100 \%$ of shares in Telewizja Polsat, which resulted in an increase in cash flows from investing activities from PLN -74,316 thousand in 2010 to PLN $2,473,859$ thousand in 2011 [12]. 
7. In 2011, PKN Orlen S.A. had total investment flows of PLN 2,490,678.00 thousand, and in 2010 - PLN 2,568,977.00 thousand. A similar situation was observed in PGE S.A., cash flows in 2010 at the level of PLN -3,547,228.00 thousand and in 2011: PLN 4,120,181.00 thousand and KGHM S.A: in 2010, investment flows at the level of: - PLN 3,125,246.00 thousand and PLN 3,590,000.00 thousand in 2011.

8. Information about sectors was taken from the Notoria database.

9. The list of sectors is given in Annex 1 to the article. 